Journal of Applied Veterinary Sciences, 5 (3): 6 - 13 (2020).

ISSN: Online: 2090-3308, Print: 1687-4072

Journal homepage : https://javs.journals.ekb.eg

\title{
Roles of Tumor Necrosis Factor in Animal Tissues : Review Article
}

\author{
H.B.Al-sabaawy ${ }^{1 *}$; Yasmeen J.M ${ }^{2}$; Enas.S.M ${ }^{1}$ and E.Al.Hamdany ${ }^{1}$ \\ ${ }^{1}$ Department of veterinary pathology and poultry Diseases, college of veterinary medicine, University of Mosul, \\ Mosul, Iraq. \\ ${ }^{2}$ Department of veterinary pathology and poultry Diseases, college of veterinary medicine, University of Basrah, \\ Basrah, Iraq. \\ *Corresponding Author, H.B. AL-Sabaawy, E-Mail: hadeelbasim2006@gmail.com
}

\begin{abstract}
Inflammation is a particular portion of tissue response to harmful inflammogens roles of it with interleukins, and systemic effects of TNF. This response including different types of inflammatory cells like (neutrophils, macrophages, lymphocytes). These cells play an essential role while inflammation occurs in Animals body by releasing competent material which acts as a chemical mediator like vasoactive amines, a proinflammatory cytokine, acute-phase proteins. These materials intercede inflammatory process by forbidding over tissue damage result in the recuperation of tissue function. This review article discusses the role and structure of tumor necrosis factor during inflammation of an animal's body.
\end{abstract}

Keywords: Chemical mediators, cytokine, interleukins, TNF, tumor necrosis factor.
Original Article:

DOI: HTTPS://DX.DOI.ORG/10.21608/JAVS.20 $\underline{20.97605}$

Received:01 May, 2020.

Accepted :31 May, 2020.

Published in July, 2020.

This is an open access article under the term of the Creative Commons Attribution 4.0 (CC-BY) International License . Tc view a copy of this license, visit http://creativecommons.org/licenses/by/4.0/

J. Appl. Vet. Sci., 5(3): 6 -13.

\section{INTRODUCTION}

Different types of chemical mediators have been produced during inflammation, infection, circulatory system injury like vasoactive amine, picosanoids, peptide (Halliwell and Gutteridge, 2015) as in table (1). These chemical mediators acts as a messenger on inflammatory cell, blood vessels which contribute to inflammatory response, cytokine define as peptide transmitters for cell to cell chatting on modulate cell functions and it divided into many types depending on it sources and function including mediators of adaptive immunity (IL-2,IL-4,IL-5,INFgmma and TNF-alpha mediators of innate immunity ( IL-1,IL-10,IL-12) and mediators of hematopoiesis (GM-CSF),TNF is one members of these mediators it is a macrophage products produce as a classical endogenous pyrogen fever in mice and rabbit, partially regulated by P38 MAPK (Montalban, et al., 2008).

It consists of two main types (TNF-alpha, TNF- Beta) involved in the innate immunity response (Clark, 2007). TNF-alpha have many synonyms (Cachectin, differentiation inducing factor, hemorrhagic factor) it secreted from different types of cell like neutrophils, macrophage, monocytes (Cawthorn and Sethi, 2008); it plays a significant role in many disease and pathological condition like Asthma (Suresh ,et al.,2004) ,TNF- $\beta$ is also called lymphotoxin and it's a pleiothopic cytokine produced by activated macrophage.

Table 1. Some types of chemical mediators

\begin{tabular}{|cccc|}
\hline & Type of CM & Source & $\begin{array}{c}\text { Mechanism of } \\
\text { action }\end{array}$ \\
\hline 1 & Prostaglandins & mast cell & $\begin{array}{c}\text { Potentiate other } \\
\text { mediators }\end{array}$ \\
\hline 2 & 2-IL-1, TNF & Macrophages & $\begin{array}{c}\text { Acute-phase } \\
\text { reactions }\end{array}$ \\
\hline 3 & Chemokine & Leukocytes & $\begin{array}{c}\text { Leukocyte } \\
\text { activation }\end{array}$ \\
\hline 4 & Leukotrienes & Leukocytes & Bronchoconstriction \\
\hline 5 & $\begin{array}{c}\text { Platelet- } \\
\text { activating } \\
\text { factor }\end{array}$ & Leukocytes & $\begin{array}{c}\text { Leukocytes priming } \\
\text { Oxidative burst }\end{array}$ \\
\hline
\end{tabular}

\section{Structure of TNF}

TNF is a trans membranes protein consist of 19 ligands and 29 receptors (Bodmer et al., 2002) comprised from two types $(T N F-\propto$ and TNF $-\beta), T N F-\propto$ composed from two antiparallel 
strands forming a jelly roll structure with an apparent molecular weight of 17-Kd (Ols Zewski et al. ,2007). Its found two forms (soluble, seconded); although the function of each form remains controversial, it has a biological trigger effect in responses to inflammation (Palladino, et al., 2003; Cawthorne and Sethi, 2008 and Taylor, 2010). TNF $-\beta$ is a potent lymphoid factor with $25 \mathrm{Kd}$ of molecular weight, found only in soluble form. Exerts cytotoxic effect on a wide range of tumor cell, induction of inflammation, antiviral responses, secondary lymphoid organ (Aggarwal, et al. ,2012); the activity of TNF-alpha and NF- Beta is a similarity both Vivo and Vitro, although they antigenically distinct (Sack, 2002). TNF as well as have two types of receptors (TNF R1, TNF R2). TNF $\mathrm{R} 1$ is mediated necrosis and apoptosis while NF R2 is much less study but it plays an important role in the regulation of T-cell( Isabelle, et al., 2004)

\section{Roles of tumor necrosis factor with interleukins}

TNF consider a strong inducer for IL-1, IL2,IL-6,IL-8 (Mattila ,et al.,1992). IL-1 is a create protein, encoded by 11distinct gene(Sims, et al., 2001), it has many equivalent names IL- $1 \propto$, IL-1 $\beta$, IL-If1, IL-1f2(Martinon, et al., 2009). The mechanism of action of IL-1 is stimulating liver cell so it concentration rises during hepatitis (Jiang and liang, 2011) and it range from one fold to one-half fold (Gebhandt, et al., 2009). TNF with IL-1 has the synergistic effect, they act on radioprotective, cytocidal influences for cartilage and bone remodeling, and some types of tumors cells, induction of the same spectrum of cytokine and their receptors lead to overlapping effects of IL1 and TNF.

IL-2 recognized for 25 years ago it receptor called $1 \mathrm{~L}-2 \mathrm{R}_{\mathrm{y}}$ (Rosen, et al., 1995) have many function like effect on immunity and stimulating of anti-tumor - immune system (Boyman and spreant ,2012), essential for development of treg-cell (Van, et al., 2013), stimulate $\mathrm{Ab}$ synthesis, differentiation of NKC, increase cytolytic function of NKC (Roediger, et al., 2015); IL-2 causes hepatic dysfunction through releasing of monokines like TNF and these leading to activation of hepatic sinusoidal endothelial cell and circulating leukocytes, that leading to endothelium adhesion and finally causing obstruction in sinusoidal microcirculation resulting in hepatic ischemia under the light microscope and demonstrates the mechanism by which IL-2 causing hepatic dysfunction (Anderson ,et al.,1996) also (Asier Gala'n ,et al.,2018) focuses on the secretion of cytokines GranulocyteMacrophage Colony-Stimulating Factor (GM-CSF), Keratinocyte Chemotactic-like (KC-like), Interleukins (IL)-2, IL-7, IL-8, IL-10, IL-15, IL-18 and Monocyte Chemotactic Protein-1 (MCP-1) in babesiosis caused by Babesia canis upon treatment with Imizol®. The result of this study confirmed a significant increase of all cytokines upon babesiosis during the first days of infection.

1L-8 identified as neutrophil and specific chemotactic factor produced by a large number of cells like lymphocyte, neutrophil, macrophage (Coelho, et al., 2005). The function of it is recruit neutrophils at the site of injury and infection (Burker, et al., 2008). These chemokines stimulate the releasing of proinflammatory cytokine as TNF and these occur in different conditions like subclinical endometritis due to the unique synthesis of blood cells and endometrial immune cells in response to inflammation (Elsayed, 2020).

1L-12 described as the NK-stimulating factor contains two light chains (p35,p40) (Zachary, 2017)it forms a link between innate resistance and adaptive immunity. TNF leading to inhibit the production of IL12and IL-23that expression by inflammatory macrophage and this effect is evident in the case of inflammatory bowel disease (Bloemendaal, et al., 2018).

\section{Biological roles of tumor necrosis factor}

These cytokines act on several types of cells and regulate the development of $\mathrm{T}$ lymphocytes, $\mathrm{B}$ lymphocytes and dendritic cells. Various cytokines have the same function like IL-1 and TNF-a which acts as inflammatory mediators or as a receptor activation or imbalances of cytokine production resulting in a various pathological disorder such as systemic lupus erythematosus, Multiple sclerosis and Rheumatoid Arthritis (Mariana and Simone, 2013); this goes back to TNF-gen which effect on the severity of disease and in predicting responses (Field, 2001, Kang, 2005) high concentration of TNF causes shock whereas the local increase in the concentration of TNF leading to appearances of main signs of the inflammatory process (redness, heat, swelling and pain).

\section{Biological roles of tumor necrosis factor in necrosis and apoptosis}

TNF is a primitive protein that has emerged for many years, TNF induced apoptosis, necrosis, and stimulating NF-KB. Apoptosis is a program cell death down by two pathway (Intrinsic like DNA damage by TNF and Fas linked (FasL), and extrinsic or receptor initiated pathway that depended on engagement of cell surface death receptor (Cory Adams, 2002, Ashkenazi, 2002).

TNF initiated apoptosis by inducing ligand (TRAIL) when TNF-K $\beta$ signaling is become blocked, $\mathrm{NF}-\mathrm{KB}$ is a vital mediator in the inflammatory 
response and stimulate by TNF family (Chen, $\boldsymbol{e t}$ al., 2008), or its include apoptosis through peptide which interbody by two pathways (1-energy-independent pathway, 2- energy-dependent pathway) leading to conserved liner sequences and disrupts cell membrane that corresponds to P12,P13 (Lu, et al., 2016).

Necrosis is an irreversible injury of the cell caused by ischemia, hypoxia. The appearance of necrotic cell differs with tissue, duration of time and causes of death. Many different types of oncotic necrosis like (coagulative necrosis, liquefactive necrosis, caseous necrosis, fibrinoid necrosis, fatty necrosis ) (Yuan and Kroemer, 2010 and Galluzzi, et al., 2011). Mechanism of necrosis include the action between Mikl(mixed lineage kinase domain-like protein) associated with Rip3(receptor-interacting serine /threonine-protein kinase) to enhance necrosome initiation which inducing by TNF- $\propto$, and this mechanism occurs due to increase RIP3 kinase activity with subsequent outphorylation which is required to form a steady combination with Mikl (Sun, et al., 2012). Death of necrotic cells is initiated by TNF-alpha and other types of death receptors like TNF-R1 (Morgan, et al., 2008). TNF has the ability to causes necrosis and apoptosis at the same time (VarfolomeeV, et al., 2012).

\section{Biological roles of tumor necrosis factor in inflammation \\ 1-Shock}

A lot of Hemodynamic investigation referred to roles of TNF in reduced filling pressures, ejection fraction and decreased cardiac output as occurs in septic shock due to overproduction of these cytokines; it acts as a pivotal mediator because of its roles in passive immunity with anti - TNF antibody, and TNF acutely released during overwhelming sepsis.

\section{2- Multiple sclerosis (MS)}

MS is a demyelinating inflammatory disease in the white matter of the central nervous system (Steinman ,1996), the effect of TNF in the central nervous system exerts both pathophysiological and homeostatic role (Santello and Volterra, 2012).

It acts on regulatory of the crucial physiological process in the central nervous system like synoptic plasticity (Kaneko, et al., 2008), while in the pathologic disorders the astrocytes especially microglia release a large amount of TNF- $\alpha$ and this is done by two mechanisms directly through increasing ionotropic and indirectly through inhibiting transport of glutamate on astrocytes and the main source of this cytokine are microglia during neuron inflammation (Welser and Milner, 2013), inflammation of neuron act as a critical role in triggers of the neurodegenerative process. Thus elevated level of TNF- $\alpha$ is found in many conditions like ischemia (liu, et al., 1994), traumatic brain injury,
Alzheimer's disease (AD) (Álvarez, et al., 2007) and Parkinson's disease PD (Boka, et al.,1994).

\section{3-Renal System effects}

TNF is produced by endothelial, epithelial cell, lymphocytes and macrophage (ImaizumI, et al, 2000). It have a pathophysiologic effect on many cardiovascular diseases like hypertension (Sriramula, et al., 2008); TNF has two types of receptors (TNF p55 and TNF P75) (Grell, et al., 1998); location of this receptor in a healthy animal is found in the cortex of proximal tubules and inside the endothelial cell of renal vascular and glomeruli (Al-Lamki, et al., 2001). Level of TNF elevated during hypertension, renal failure and glomerular nephritis (EI Marakby, et al., 2008; Ramesh and Reeves 2004 ; Vielhaur, et al., 2005). Its concentration increase during nephritis, which companied by large infiltration of macrophage (Parane Swaran and Patial, 2010), as well as its level elevated during diabetic nephropathy( Gohdat, et al., 2012).

\section{4-Inflammatory bowel disease (IBD)}

IBD is an idiopathic disease and there are two types of it ulcerative colitis and Crohen's disease (Jergens, 2012) TNF causes invasive stimuli (tissue injury) or infectious agent by regulating the metabolic activity process and activating of neutrophils and changes properties of endothelial cell and the TNF is inducing a state of wasting and anorexia that similar to many infectious diseases and chronic neoplasia (Peterson, et al., 2010); IL-10 and TGF-B play essential roles in maintaining intestinal homeostasis encoding gene of both leading to inflammatory bowel disease in human while in mice it caused micro Bialy leading to inducing of pro-inflammatory cytokines INF- $\alpha$ and INF- $\gamma$ (Kang, et al., 2008).

\section{5-Role of tumor necrosis factor in inflammation of lab animals}

Animal models are using during inflammation to assess the production of inflammatory mediators at sites of inflammation, when we inject animal with any foreign material, bacteria ,or even irritant agent, its might get a fever, its heart rate increase and breathing might start to increase also, this means response to inflammation. inflammatory reactions comprise a sequence of events such as acute and chronic inflammations, foreign body reaction, granulation tissue generation and fibrous encapsulation (or fibrosis) (Djane, 2012). The subcutaneous air pouch is an in vivo model that can be used to study the components of inflammation ( both acute and chronic), the oxidative stress response and the resolution of the inflammatory response. Injection of irritants into an air pouch in mice or rats induces an inflammatory response and releasing of an inflammatory mediators.

Micheal, (2018) mentioned that Injection of a carrageenan solution into the pouch produces an 
inflammatory reaction that is characterized by an infiltration of inflammatory cells, exudation, and a marked production of pro-inflammatory mediators, such as prostaglandins, cytokines, leukotrienes, as well as components of the oxidative stress response. The progression of inflammatory reactions is mediated by a number of chemical mediators released from plasma cells and tissues, including growth factor ,cytokines, plasma proteases, platelet activating factor, lysosomal proteases and vasoactive amines.

Activation of inflammatory cell like ( neutrophils , macrophages) lead to phagocytosis of foreign materials, which may last until the stage of chronic inflammation. Macrophage plays an important role in the inflammation by secreting a number of chemical mediators (e.g., neutral proteases, growth factor and oxygen free radicals) that regulate inflammatory responses and possibly cause systemic effects in organs or tissues (Kang, et al.,2008).

Biological roles of tumor necrosis factor in autoimmune diseases Rheumatoid arthritis (RA)

$\mathrm{RA}$ is an autoimmune disorder and most common inflammatory joint characterized by synovial inflammation, swelling, hyperplasia, disturbances of anti-citrullinated protein antibody (AC-PA), bone destruction and finally leading to a systemic defect like skeletal disorder (McInnes and Schett, 2011;Kimura, 2017), RA affects about (0.5-1.0\%) of the population (Kaipianen, 2001) this diseases mediated by T-helper cell type 1 also there is increased in cytokine type 17 (th17) which produce interleukin 17f, 17A,22 and also create TNF- $\alpha$ (Sutton, et al., 2009).

The activation of CD+ Tcell also stimulate Bcell and lead to the production of immunoglobulin, including Rheumatoid factor (RF) this factor effect on complement through the formation of immune complex (Burbano, et al., 2015)in addition to the role of TGF-B with TNF- $\alpha$ which consider as a pleiotropic cytokine in the inflammatory process, for instance, injection of rats with TGF-B leading to synovial inflammation and swelling of joint (Allen, et al., 1990) early detection of pro-inflammatory cytokine in Rheumatoid arthritis is depended on biopsy and cutter established the important role of this cytokine in joint inflammation (Feldmann, et al., 1996).

\section{Biological roles of tumor necrosis factor in cancer} Interleukins (ILs) play an essential role in cancer as potential modulators of leukocyte infiltration, angiogenesis, and tumor growth. The study applied to dogs having inflammatory mammary cancer ( IMC) was to assess serum and tumor levels of several ILs (IL-1 $\alpha$, IL-1 $\beta$, IL-6, IL-8, and IL-10) by enzymeimmunoassay in the dogs that bearing malignant and benign mammary tumors. IL-8 (serum) and IL-10 (serum and tissue homogenate) levels were higher in the dogs with Inflammatory mammary cancer ( IMC) compared with the non-IMC group. IL-8 was increased in malignant tumors. To the best of our knowledge, this is the first report that analyzes ILs in IMC and IL-10 in canine mammary tumors(De Andres, et al., 2013). TNFs plays an important role in chemotherapy by enhancing the efficacy of it; so that it useful in the regional treatment of soft tissue sarcoma and metastatic melanoma.

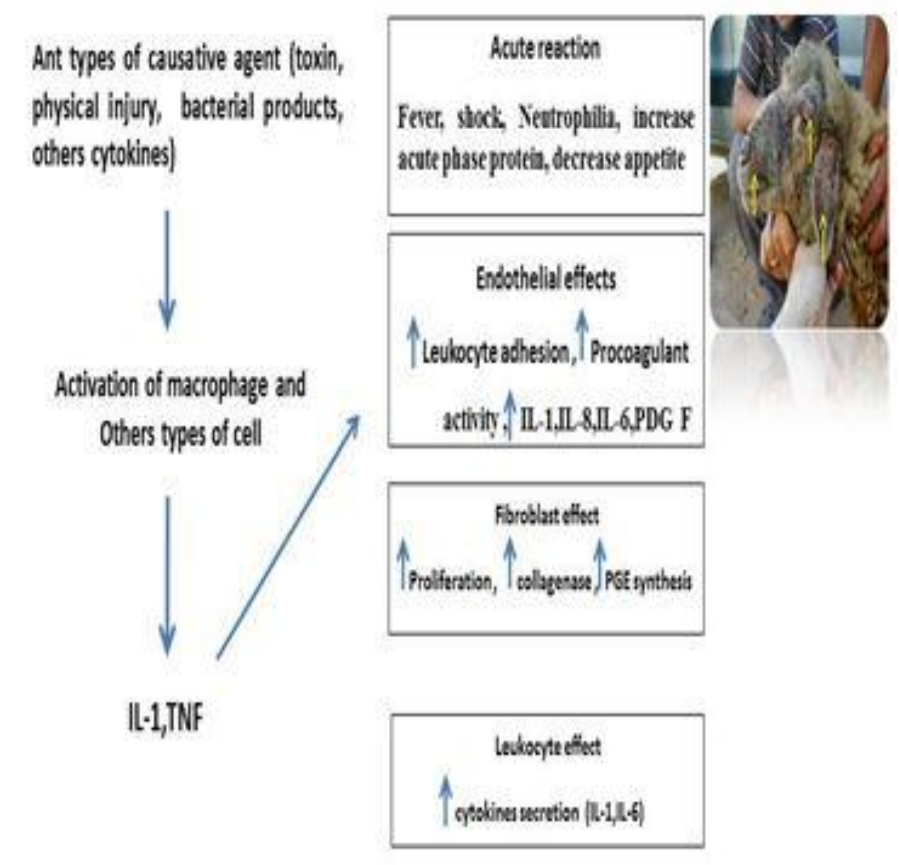

Diagram: shows the effects of IL-1 with TNF in inflammation (Elsevier, 2005).

\section{CONCLUSIONS}

Although inflammation plays important roles in the elimination of different types of causative agents that leading to pathogenicity in vivo and in vitro,the prolonged inflammatory process may resulting in a chronic disease or even failure of organ function so that this article focused on roles of chemical mediators especially tumor necrosis factor in the inflammatory process.

\section{REFERENCES}

AGGARWAL, B.B., GUPTA, S.C. AND KIM, J.H. 2012. Historical perspectives on tumor necrosis factor and its superfamily: 25 years later, a golden journey. Blood. American Society of Hematology; 9;119(3):651-65. DOI.org/10.1182/blood-2011-04-325225.

AL-LAMKI R.S., WANG, J., SKEPPER, J.N., THIRU. S., POBER. J.S. AND BRADLEY. J.R. 2001. Expression of Tumor Necrosis Factor Receptors in Normal Kidney and Rejecting Renal Transplants. Laboratory Investigation. Springer Science and 
Business Media LLC; 81(11):1503-15. DOI.org/10.1038/labinvest.3780364.

ALLEN, J.B., MANTHEY, C.L., HAND, A.R., OHURA, K., ELLINGSWORTH, L. AND WAHL, S.M. 1990. Rapid onset synovial inflammation and hyperplasia induced by transforming growth factor-beta. The Journal of Experimental Medicine. Rockefeller University Press; $1 ; 171(1): 231-47$.

DOI.org/10.1084/jem.171.1.231.

ÁlVAREZ, A., CACABElOS, R., SANPEDRO, C., GARCÍA-FANTINI, M. AND ALEIXANDRE, M. 2007. Serum TNF-alpha levels are increased and correlate negatively with free IGF-I in Alzheimer's disease. Neurobiology of Aging. Elsevier BV; 28(4):533-6.

DOI.org/10.1016/j.neurobiolaging.2006.02.012.

ANDERSON, J.A., LENTSCH, A.B., HADJIMINAS, D.J., MILLER, F.N., MARTIN, A.W. AND NAKAGAWA, K. 1996. The role of cytokines, adhesion molecules, and chemokines in interleukin-2induced lymphocytic infiltration in C57BL/6 mice. Journal of Clinical Investigation. American Society for Clinical Investigation; 15;97(8):1952-9. DOI.org/10.1172/jci118627.

ASHKENAZI, A., 2002. Targeting death and decoy receptors of the tumor necrosis factor superfamily. Nature Reviews Cancer. Springer Science and Business Media LLC; 2(6):420-30. DOI.org/10.1038/nrc821.

ASIER GALA'N, IVA MAYER, RENATA BARIĆ RAFAJ , KRES`O BENDELJA , VELIMIR SUS`IĆ , JOSE' JOAQUI'N CERO'N , VLADIMIR MRLJAK.,2018. MCP-1, KC-like and IL-8 as critical mediators of pathogenesis caused by Babesia canis. PLoS One.; 13(1): e0190474.

DOI: 10.1371/journal.pone.0190474.

BLOEMENDAAL, F.M., KOELINK PJ, V.A.N., SCHIE, K.A., RISPENS, T., PETERS, C.P. AND BUSKENS, C.J. 2018. TNF-anti-TNF Immune Complexes Inhibit IL-12/IL-23 Secretion by Inflammatory Macrophages via an Fc-dependent Mechanism. Journal of Crohn's and Colitis. Oxford University Press (OUP); 30;.DOI.org/10.1093/eccojcc/jjy075.

BODMER, J-L., SCHNEIDER, P. And TSCHOPP, J. 2002. The molecular architecture of the TNF superfamily. Trends in Biochemical Sciences. Elsevier BV; 27(1):19-26. DOI.org/10.1016/s0968-0004 (01): 01995-8.

BOKA, G., ANGLADE, P., WALLACH, D., JAVOY AGID, F., AGID, Y. AND HIRSCH, E.C. 1994. Immunocytochemical analysis of tumor necrosis factor and its receptors in Parkinson's disease. Neuroscience Letters, Vol. 172, No.1-2, pp.151-154.

BOKA, G., ANGLADE, P., WALLACH, D., JAVOY AGID, F., AGID, Y. AND HIRSCH, E.C. 1994. Immunocytochemical analysis of tumor necrosis factor and its receptors in Parkinson's disease. Journal Article published in Neuroscience Letters volume 172 issue 12 on pages 151 to 154 .

BOYMAN, O. AND SPRENT, J., 2012. The role of interleukin-2 during homeostasis and activation of the immune system. Nature Reviews Immunology.
Springer Science and Business Media LLC; 17;12(3):180-90. DOI.org/10.1038/nri3156.

BURBANO, C., ROJAS, M., VÁSQUEZ, G. AND CASTAÑO, D. 2015. Microparticles That Form Immune Complexes as Modulatory Structures in Autoimmune Responses. Mediators of Inflammation. Hindawi Limited; 2015:1-15. DOI.org/10.1155/2015/267590.

BURKER, S.M., ISSEKUTZ, T.B., MOHAN, K., LEE, P.W., SHMULEVITZ, M. AND MARSHALL, J.S., 2008. Human mast cell activation with virus-associated stimuli leads to the selective chemotaxis of natural killer cells by a CXCL8-dependent mechanism. Blood; 111(12), pp.5467-5476.

CARPENTIER, I., COORNAERT, B. AND BEYAERT R. 2004. Function and Regulation of Tumor Necrosis Factor Receptor Type 2. Current Medicinal Chemistry. Bentham Science Publishers Ltd.; 1;11(16):2205-12. DOI.org/10.2174/0929867043364694.

CAWTHORN, W.P. AND SETHI, J.K. 2007. TNF- $\alpha$ and adipocyte biology. FEBS Letters. Wiley; 26;582(1):117-31.

DOI.org/10.1016/j.febslet.2007.11.051.

CHEN, N.J., CHIO, IIC., LIN, W-J., DUNCAN, G., CHAU, H. AND KATZ, D. 2008. Beyond tumor necrosis factor receptor: TRADD signaling in toll-like receptors. Proceedings of the National Academy of Sciences. Proceedings of the National Academy of Sciences; 21;105(34):12429-34 DOI.org/10.1073/pnas.0806585105.

CLARK, I. 2007. How TNF was recognized as a key mechanism of disease. Cytokine \& Growth Factor Reviews. Elsevier BV; 18(3-4):335-43. DOI.org/10.1016/j.cytogfr.04.002.

CLAY, GOODMAN, J., ROBERTSON, C.S., GROSSMAN, R.G., AND NARAYAN, R.K. 1990. Elevation of tumor necrosis factor in head injury. Journal of Neuroimmunology . Elsevier BV; 30(23):213-7. DOI.org/10.1016/0165-5728(90)90105-v.

COELHO, A.L., HOGABOAM, C.M. AND KUNKEL, S.L. 2005. Chemokines provide the sustained inflammatory bridge between innate and acquired immunity. Cytokine and Growth Factor Reviews. Elsevier BV; 16(6):553-60. DOI.org/10.1016/j.cytogfr.2005.03.004.

COLLINS, T., READ, M.A., NEISH, A.S., WHITLEY, M.Z., THANOS, D. AND MANIATIS T. 1995. Transcriptional regulation of endothelial cell adhesion molecules: NF- $\kappa \mathrm{B}$ and cytokine-inducible enhancers. The FASEB Journal. Wiley; 9(10):899-909. DOI.org/10.1096/fasebj.9.10.7542214.

CORY, S. AND ADAMS, J.M., 2002. The Bcl2 family: regulators of the cellular life-or-death switch. Nature Reviews Cancer. Springer Science and Business Media LLC; 2(9):647-56. DOI.org/10.1038/nrc883.

DE ANDRES PJ, ILLERA JC, CACERES S, DIEZ L, PEREZ-ALENZA MD, PENA L.,2013. Increased levels of interleukins 8 and 10 as findings of canine inflammatory mammary cancer. Veterinary Immunology and Immunopathology; 152(3-4):245-51. https://DOI.org/10.1016/j.vetimm.2012.12.010PMID: 23351639. 
DJANE B. DUARTE, MICHAEL R. VASKO,JILL C. FEHRENBACHER.,2012, Models of Inflammation: Carrageenan Air Pouch. Curr Protoc Pharmacol. Mar;CHAPTER5:Unit5.6.DOI: 10.1002/0471141755.p h0506s56.

DINARELLO, C.A., 2009. Immunological and Inflammatory Functions of the Interleukin-1 Family. Annual Review of Immunology. Annual Reviews; 27(1):519-550. DOI.org/10.1146/annurev.immunol.021908.132612.

ELMARAKBY, A.A., QUIGLEY, J.E., IMIG, J.D., POLLOCK, J.S. AND POLLOCK, D.M. 2008. TNF$\alpha$ inhibition reduces renal injury in DOCA-salt hypertensive rats. American Journal of PhysiologyRegulatory, Integrative and Comparative Physiology. American Physiological Society; 294(1): R76-R83. DOI.org/10.1152/ajpregu.00466.2007.

ELSAYED, D.H., EL-AZZAZI, F.E., MAHMOUD, Y.K., DESSOUKI, S.M. AND AHMED, E.A. 2020. Subclinical endometritis and postpartum ovarian resumption in respect to TNF- \pm , IL-8 and CRP in Egyptian buffaloes. Animal Reproduction. Colegio Brasileiro de Reproducao Animal - CBRA; 17(1.DOI.org/10.21451/1984-3143-ar2019-0027.

ELSEVIER ADVANCED TECHNOLOGY. 2005. Metal powders. Elsevier. Xv.DOI.org/10.1016/b978185617479-4/50003-X.

FELDMANN, M. AND BRENNAN, F.M., 1996. Maini RN. ROLE OF CYTOKINES IN RHEUMATOID ARTHRITIS. Annual Review of Immunology. Annual Reviews; 14(1):397-440.

DOI.org/10.1146/annurev.immunol.14.1.397.

FIELD, M. 2001. Tumour necrosis factor polymorphisms in rheumatic diseases. QJM. Oxford University Press (OUP); 1;94(5):237-46.

DOI.org/10.1093/qjmed/94.5.237.

GALLUZZI, L., VITALE, I., ABRAMS, J.M., ALNEMRI, E.S., BAEHRECKE, E.H., AND BLAGOSKLONNY, M.V. 2011. Molecular definitions of cell death subroutines: recommendations of the Nomenclature Committee on Cell Death 2012. Cell Death \& Differentiation. Springer Science and Business Media LLC; 15;19(1):10720.DOI.org/10.1038/cdd.2011.96.

GEBHARDT, C., HIRSCHBERGER， J., RAU， S., ARNDT, G., KRAINER, K. AND SCHWEIGERT, F.J. 2009. Use of C-reactive protein to predict outcome in dogs with systemic inflammatory response syndrome or sepsis. Journal of Veterinary Emergency and Critical Care. Wiley; 19(5):450-8. DOI.org/10.1111/j.14764431.2009.00462.x.

GOHDA, T., NIEWCZAS, M.A., FICOCIELLO, L.H., WALKER, W.H., SKUPIEN, J. AND ROSETTI, F. 2012. Circulating TNF Receptors 1 and 2 Predict Stage 3 CKD in Type 1 Diabetes. Journal of the American Society of Nephrology. American Society of Nephrology (ASN); 19;23(3):516-24. DOI.org/10.1681/asn.2011060628.

GRELL, M., EAJANT, H., IMMERNANN, G. AND SCHEUICH, P. 1998. The type 1 receptor (CDL 20a) is the high-affinity receptor for soluble tumor necrosis factor proc. Natl Acad Sci USA, 5: 570-575.
HALLIWELL, B. AND GUTTERIDGE, J.M.C., 2015. Free Radicals in Biology and Medicine. Oxford University Press; 1.

DOI.org/10.1093/acprof:oso/9780198717478.001.0001.

IMAIZUMI, T., ITAYA, H., FUJITA, K., KUDOH, D., KUDOH, S. AND MORI, K. 2000. Expression of Tumor Necrosis Factor- $\alpha$ in Cultured Human Endothelial Cells Stimulated With Lipopolysaccharide or Interleukin-1 $\alpha$. Arteriosclerosis, Thrombosis, and Vascular Biology. Ovid Technologies (Wolters Kluwer Health); 20(2):410-415.

ISABELLE, C., BEATRICE, C. AND RUDI, B. 2004. Current Medicinal Chemistry 11(16):2205-12, DOI: 10.2174/0929867043364694

ISSEKUTZ, S.M., MOHAN, T.B.K., LEE, P.W.K., SHMULEVITZ, M. P. AND MARSHALL, J.S. 2008. Human mast cell activation with virus-associated stimuli leads to the selective chemotaxis of natural killer cells by a CXCL8-dependent mechanism. Blood. American Society of Hematology; 15;111(12):546776. DOI.org/10.1182/blood-2007-10-118547.

JERGENS, A.E., 2012. Inflammatory bowel disease in veterinary medicine. Frontiers in Bioscience. Frontiers in Bioscience; E4(4):1404-19. DOI.org/10.2741/e470.

JIANG, D., LIANG, J. AND NOBLE, P.W., 2011. Hyaluronan as an Immune Regulator in Human Diseases. Physiological Reviews. American Physiological Society; 91(1):221-64. DOI.org/10.1152/physrev.00052.2009.

KAIPIAINEN-SEPPANEN, O., 2001. Regional differences in the incidence of rheumatoid arthritis in Finland in 1995. Annals of the Rheumatic Diseases. BMJ; 1;60(2):128-32. DOI.org/10.1136/ard.60.2.128.

KANEKO, D. STELLWAGEN, R.C. MALENKA, M.P. S TRYKER. 2008. Tumor necrosis factor-alpha mediates one component of competitive, experience-dependent plasticity in developing visual cortex Neuron; 58 pp. 673-680.

KANG, C.P., 2005. The influence of polymorphism at position -857 of the tumour necrosis factor gene on clinical response to etanercept therapy in rheumatoid arthritis. Rheumatology. Oxford University Press (OUP); 3;44(4):547-52.

DOI.org/10.1093/rheumatology/keh550.

KANG, C.P., 2005. The influence of a polymorphism at position -857 of the tumour necrosis factor gene on clinical response to etanercept therapy in rheumatoid arthritis. Rheumatology. Oxford University Press (OUP); 3;44(4):547-52. DOI.org/10.1093/rheumatology/keh550.

KANG, S.S., BLOOM, S.M., NORIAN. L.A, GESKE, M. J., FLAVEL, L.R.A., STAPPENBECK, T, AND ALLEN, P.M. 2008. An antibiotic-responsive mouse model of fulminant ulcerative colitis. PLoS Med 5: e41.

KIMURA, T., 2017. Canine rheumatoid arthritis characterized by hyperprolactinemia. Veterinary Science Development. PAGE Press Publications; 10;7(1). DOI.org/10.4081/vsd.2017.6463.

LIU, T., CLARK, R.K., MCDONNELL, P.C., YOUNG, P.R., WHITE, R.F., BARONE, F.C. AND ET, A.L. 1994. Tumor necrosis factor-alpha expression in ischemic neurons. Stroke. Ovid Technologies (Wolters Kluwer Health); 25(7):1481-8. 
DOI.org/10.1161/01.str.25.7.1481.

LU, W., CHEN, Q., YING, S., XIA, X., YU, Z. AND LUI, Y. 2016. Evolutionarily conserved primary TNF sequences relate to its primitive functions in cell death induction. Journal of Cell Science [Internet]. The Company of Biologists; 1;129(1):108-20. DOI.org/10.1242/jcs.175463.

MARIANA, P. AND SIMONE, A., 2013. January The role of tumor necrosis factor-alpha in autoimmunity.

MARTINON, F., MAYOR, A. AND TSCHOPP, J. 2009. The Inflammasomes: Guardians of the Body. Annual Review of Immunology. Annual Reviews; 27(1):229. DOI.org/10.1146/annurev.immunol.021908.132715.

MATTILA, P., MAJURI M, L., MATTILA, P.S. AND RENKONEN, R. 1992. TNFa-Induced Expression of Endothelial Adhesion Molecules, ICAM-1 and VCAM1 , is Linked to Protein Kinase C Activation. Scandinavian Journal of Immunology. Wiley; 36(2):159-66.

DOI.org/10.1111/j.13653083.1992.tb03087.x.

MCINNES, I.B. AND SCHETT, G. 2011. The Pathogenesis of Rheumatoid Arthritis. New England Journal of Medicine. Massachusetts Medical Society; 365(23):2205-19. DOI.org/10.1056/nejmra1004965.

MICHAEL R VASKO, DJANE B DUARTEJILL C FEHRENBACHER.,2012. Models of Inflammation: Carrageenan- Or Complete Freund's Adjuvant (CFA)induced Edema and Hypersensitivity in the Rat.Curr Protoc.Mar;Chapter5:Unit5.4 Pharmacol. DOI: 10.1002/0471141755.ph0504s56. .

MONTALBAN, A.G., BOMAN, E., CHANG, C.D., CEIDE, S.C., DAHL, R. AND DALESANDRO, D. 2008. The design and synthesis of novel $\alpha$-ketoamidebased p38 MAP kinase inhibitors. Bioorganic \& Medicinal Chemistry Letters. Elsevier BV;18(6):1772. DOI.org/10.1016/j.bmcl.2008.02.033.

MORGAN, M.J., KIM, Y.S. AND LIU, Z. 2008. TNFa and reactive oxygen species in necrotic cell death. Cell Research. Springer Science and Business Media LLC; 26;18(3):343-9. DOI.org/10.1038/cr.2008.31.

OLSZEWSKI, M.B., GROOT, A.J., DASTYCH, J. AND KNOL, E.F. 2007. TNF Trafficking to Human Mast Cell Granules: Mature Chain-Dependent Endocytosis. The Journal of Immunology. The American Association of Immunologists; 18;178(9):5701-9. DOI.org/10.4049/jimmunol.178.9.5701.

PALLADINO, M.A., BAHJAT, F.R., THEODORAKIS, E.A. AND MOLDAWER, L.L. 2003. Anti-TNF- $\alpha$ therapies: the next generation. Nature Reviews Drug Discovery. Springer Science and Business Media LLC; 2(9):736-46. DOI.org/10.1038/nrd1175.

PETERSON, K.M., MONDAL, D., PETRI, W.A., DUGGAL, P., HAQUE, R. AND SHU, J. 2010. Association between TNF- $\alpha$ and Entamoeba histolytica Diarrhea. The American Journal of Tropical Medicine and Hygiene. American Society of Tropical Medicine and Hygiene; 1;82(4):620-5. DOI.org/10.4269/ajtmh.2010.09-0493.

RAMESH, G., REEVES, W.B., 2004. Inflammatory cytokines in acute renal failure. Kidney International. Elsevier BV; 66:S56-S61. DOI.org/10.1111/j.15231755.2004.09109.x.
ROEDIGER, B., KYLE, R., TAY, S.S., MITCHELL, A.J., BOLTON, H.A. AND GUY, T.V. 2015. IL-2 is a critical regulator of group 2 innate lymphoid cell function during pulmonary inflammation. Journal of Allergy and Clinical Immunology. Elsevier BV; 136(6):1653-1663.e7.

DOI.org/10.1016/j.jaci.2015.03.043.

ROSEN, F.S., COOPER, M.D. AND WEDGWOOD, R.J.P. 1995. The Primary Immunodeficiencies. New England Journal of Medicine. Massachusetts Medical Society; 17;333(7):431-40.

DOI.org/10.1056/nejm199508173330707.

SACK, M.N., 2002. Tumor necrosis factor- $\alpha$ in cardiovascular biology and the potential role for antitumor necrosis factor- $\alpha$ therapy in heart disease. Pharmacology \& Therapeutics. Elsevier BV; 94(12):123-35. DOI.org/10.1016/s0163-7258(02)00176-6.

SANTELLO, M. AND VOLTERRA, A., 2012. TNF $\alpha$ in synaptic function: switching gears. Trends in Neurosciences. Elsevier BV; 35(10):638-47. DOI.org/10.1016/j.tins.2012.06.001.

SIMS, J.E., PAN, Y., SMITH, D.E., NICKLIN, M.J., BARTON, J.L., BAZAN, J.F., KASTELEIN, R.A., BUSFIELD, S.J., FORD, J.E., LIN, H. AND MULERO, J.J. 2001. A new nomenclature for IL-1family genes. Trends in immunology; Vol. 22, no.10, pp.536-537.

SRIRAMULA, S., HAQUE, M., MAJID, D.S.A. AND FRANCIS, J. 2008. Involvement of Tumor Necrosis Factor- $\alpha$ in Angiotensin II-Mediated Effects on Salt Appetite, Hypertension, and Cardiac Hypertrophy. Hypertension. Ovid Technologies (Wolters Kluwer Health); 51(5):1345-51.

DOI.org/10.1161/hypertensionaha.107.102152.

STEINMAN, M.D.L., 1996. Multiple Sclerosis: A Coordinated Immunological Attack against Myelin in the Central Nervous System. Cell. Elsevier BV; 85(3):299-302.DOI.org/10.1016/s0092-8674(00)81107-1.

SUN, L., WANG, H., WANG, Z., HE, S., CHEN, S., LIAO, D., WANG, L., YAN, J., LIU, W., LEI, X. AND WANG, X. 2012. Mixed lineage kinase domainlike protein mediates necrosis signaling downstream of RIP3 kinase. Cell. 148:213-227.

SURESH K.B., DONNA, D. AND STEPHEN, H. 2004. Role of tumor necrosis factor-alpha in asthma Immunology and Allergy Clinics of North America 24(4):583-97,DOI: 10.1016/j.iac.2004.06.010.

SUTTON, C.E., LALOR, S.J., SWEENEY, C.M., BRERETON, C.F., LAVELLE, E.C. AND MILLS, K.H.G. 2009. Interleukin-1 and IL-23 Induce Innate IL-17 Production from T Cells, Amplifying Th17 Responses and Autoimmunity. Immunity. Elsevier $\mathrm{BV} ; 31(2): 331-41$.

DOI.org/10.1016/j.immuni.2009.08.001.

TAYLOR, P.C., 2010. Pharmacology of TNF blockade in rheumatoid arthritis and other chronic inflammatory diseases. Current Opinion in Pharmacology. Elsevier BV;10(3):308-15.DOI.org/10.1016/j.coph.2010.01.005.

VAN, D.E., VEEN, W., STANIC, B., YAMAN, G., WAWRZYNIAK, M., SÖLLNER, S. AND AKDIS, D.G. 2013. IgG4 production is confined to human IL10-producing regulatory B cells that suppress antigenspecific immune responses. Journal of Allergy and 
Clinical Immunology. Elsevier BV; 131(4):1204-12. DOI.org/10.1016/j.jaci.2013.01.014.

VARFOLOMEEV, E., GONCHAROV, T., MAECKER, H., ZOBEL, K., KOMUVES, L.G. AND DESHAYES, K. 2012. Cellular Inhibitors of Apoptosis Are Global Regulators of NF- B and MAPK Activation by Members of the TNF Family of Receptors. Science Signaling. American Association for the Advancement of Science (AAAS);20;5(216):ra22-ra22.

DOI.org/10.1126/scisignal.2001878.

VIELHAUER, V., STAVRAKIS, G. AND MAYADAS, T.N., 2005. Renal cell-expressed TNF receptor 2, not receptor 1 , is essential for the development of glomerulonephritis. Journal of Clinical Investigation. American Society for Clinical Investigation; 1;115(5):1199-209. DOI.org/10.1172/jci200523348.

WELSER-ALVES, J.V. AND MILNER, R. 2013. Microglia are the major source of TNF- $\alpha$ and TGF- $\beta 1$ in postnatal glial cultures, regulation by cytokines, lipopolysaccharide, and vitronectin. Neurochemistry International. Elsevier BV; 63(1):47-53. DOI.org/10.1016/j.neuint.2013.04.007.

YUAN, J. AND KROEMER, G., 2010. Alternative cell death mechanisms in development and beyond. Genes
\& Development. Cold Spring Harbor Laboratory; 1;24(23):2592-602. DOI.org/10.1101/gad.1984410.

ZACHARY, J.F., 2017. Preface. Pathologic Basis of Veterinary Disease. Elsevier; vii-ix.

DOI.org/10.1016/b978-0-323-35775-3.00028-x.

How to cite this article:

H.B.Al-Sabaawy; Yasmeen J.M; Enas.S.M and E.Al.Hamdany, 2020. Roles of Tumor Necrosis Factor in Animal Tissues : Review Article. Journal of Applied Veterinary Sciences, 5(3): 6 13.

DOI: $\underline{\text { HTTPS://DX.DOI.ORG/10.21608/JAVS.2020.97605 }}$ 